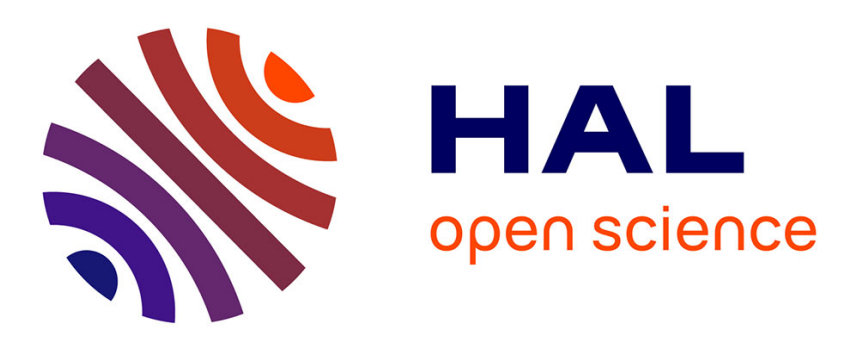

\title{
Producer responsibility and recycling solar photovoltaic modules
}

\author{
N.C. C Mcdonald, J.M. Pearce
}

\section{To cite this version:}

N.C. C Mcdonald, J.M. Pearce. Producer responsibility and recycling solar photovoltaic modules.

Energy Policy, 2010, 38 (11), pp.7041-7047. 10.1016/j.enpol.2010.07.023 . hal-02120502

\section{HAL Id: hal-02120502 \\ https://hal.science/hal-02120502}

Submitted on 6 May 2019

HAL is a multi-disciplinary open access archive for the deposit and dissemination of scientific research documents, whether they are published or not. The documents may come from teaching and research institutions in France or abroad, or from public or private research centers.
L'archive ouverte pluridisciplinaire HAL, est destinée au dépôt et à la diffusion de documents scientifiques de niveau recherche, publiés ou non, émanant des établissements d'enseignement et de recherche français ou étrangers, des laboratoires publics ou privés. 
Published as: N.C. McDonald and J. M. Pearce, "Producer responsibility and recycling solar photovoltaic modules”, Energy Policy 38, pp. $7041-7047$ (2010). http://dx.doi.org/10.1016/j.enpol.2010.07.023

\title{
Producer Responsibility and Recycling Solar Photovoltaic Modules
}

\author{
N. C. McDonald (1) and J. M. Pearce (1,2)* \\ (1) School of Environmental Studies \\ (2) Department of Mechanical and Materials Engineering \\ Queen's University \\ * Corresponding author: 60 Union Street, Kingston, Ontario, K7L 3N6 Canada \\ ph:613-533-3369
}

email: pearce@me.queensu.ca

\begin{abstract}
Rapid expansion of the solar photovoltaic (PV) industry is quickly causing solar to play a growing importance in the energy mix of the world. Over the full life cycle, although to a smaller degree than traditional energy sources, PV also creates solid waste. This paper examines the potential need for PV recycling policies by analyzing existing recycling protocols for the five major types of commercialized PV materials. The amount of recoverable semiconductor material and glass in a $1 \mathrm{~m}^{2}$ area solar module for the five types of cells is quantified both physically and the profit potential of recycling is determined. The cost of landfill disposal of the whole solar module, including the glass and semiconductor was also determined for each type of solar module. It was found that the economic motivation to recycle most PV modules is unfavorable without appropriate policies. Results are discussed on the need to regulate for appropriate energy and environmental policy in the PV manufacturing industry particularly for PV containing hazardous materials. The results demonstrate the need to encourage producer responsibility not only in the PV manufacturing sector, but also the entire energy industry.
\end{abstract}

Keywords: recycling; photovoltaic; manufacturing; manufacturing responsibility

\section{Introduction}

As the negative effects of anthropogenic climate destabilization become more pronounced (IPCC, 2008), greater attention is being paid to life cycle carbon emissions (Kenny et al., 2010) and low emission renewable energy sources such as solar photovoltaic (PV) technology are experiencing rapid growth (EPIA, 2009). Many countries in Europe have already benefited from this strong PV growth both economically and environmentally, and have demonstrated to the rest of the world that PV technology is a promising (Jäger-Waldau, 2007) and a truly sustainable (Pearce, 2002) energy source. In addition to the clear environmental benefits (Frantzeskaki et al., 2005; Castanas and Kampa, 2008), there is also a clear financial benefit for governments to encourage PV manufacturing in their region because of the concomitant large relative 
Published as: N.C. McDonald and J. M. Pearce, "Producer responsibility and recycling solar photovoltaic modules”, Energy Policy 38, pp. 7041-7047 (2010). http://dx.doi.org/10.1016/j.enpol.2010.07.023

job creation to other energy-related industries (Pembina Institute, 1997; Branker and Pearce, 2010). These properties have enabled the PV industry to garner enormous public support, with a recent poll finding that $92 \%$ of U.S. citizens support the development and use of solar technology (Cheyney, 2009). However, with this rapid expansion of the PV industry buoyed by public support, it is anticipated that there will be a remarkably large challenge of waste disposal in 25 to 30 years (Fthenakis, 2000).

Often PV technology is considered an energy source that has very minimal waste because there is none produced during operation and the more traditional electricity sources are so environmentally damaging. Although, PV-related solid waste is minute in comparison to the waste associated with traditional energy sources, there is still waste that can not be ignored that is created by the decommissioning of the solar modules at the end of their lives. As the PV market continues to grow, so will waste, even if it only appears after a relatively long time delay. This is due to the fact that the industry generally provides $25-30$ year warranties for the power produced, which consequently is the life cycle for a module to still perform at $80 \%$ of its initial energy output (Kazmerski, 2006). Additionally, with the recent increased cell efficiencies and decreasing production costs, the PV industry has grown tremendously. In 2000 the total world PV production was $278 \mathrm{MW}$ compared to the 5,559 MW produced in 2008, and the 7,300 MW produced in 2009 (EPIA, 2009; Solar Buzz, 2010).

Unlike other industries, PV waste is unique because it has a long (approximately generational) lag time from the time it is produced to the time it is decommissioned. Figure 1 shows the global PV production in the decade between 1998 and 2008 (EPIA, 2009) and the concomitant expected waste until 2038 assuming the historical percentages and efficiencies of thin film and silicon-based technologies and an end of life matching the warranty lag. The amount of PV modules created for any one of these years will correlate to the amount of PV waste that will exist assuming that modules are retired after their warranty has expired as seen in Figure 1. As can be seen in Figure 1 the amount of waste (still quantified in installed power units) can vary dramatically after 2030 based on the actualized lifetime of the modules and the dramatic growth experienced in the PV industry in the last decade. 
Published as: N.C. McDonald and J. M. Pearce, "Producer responsibility and recycling solar photovoltaic modules”, Energy Policy 38, pp. $7041-7047$ (2010). http://dx.doi.org/10.1016/j.enpol.2010.07.023

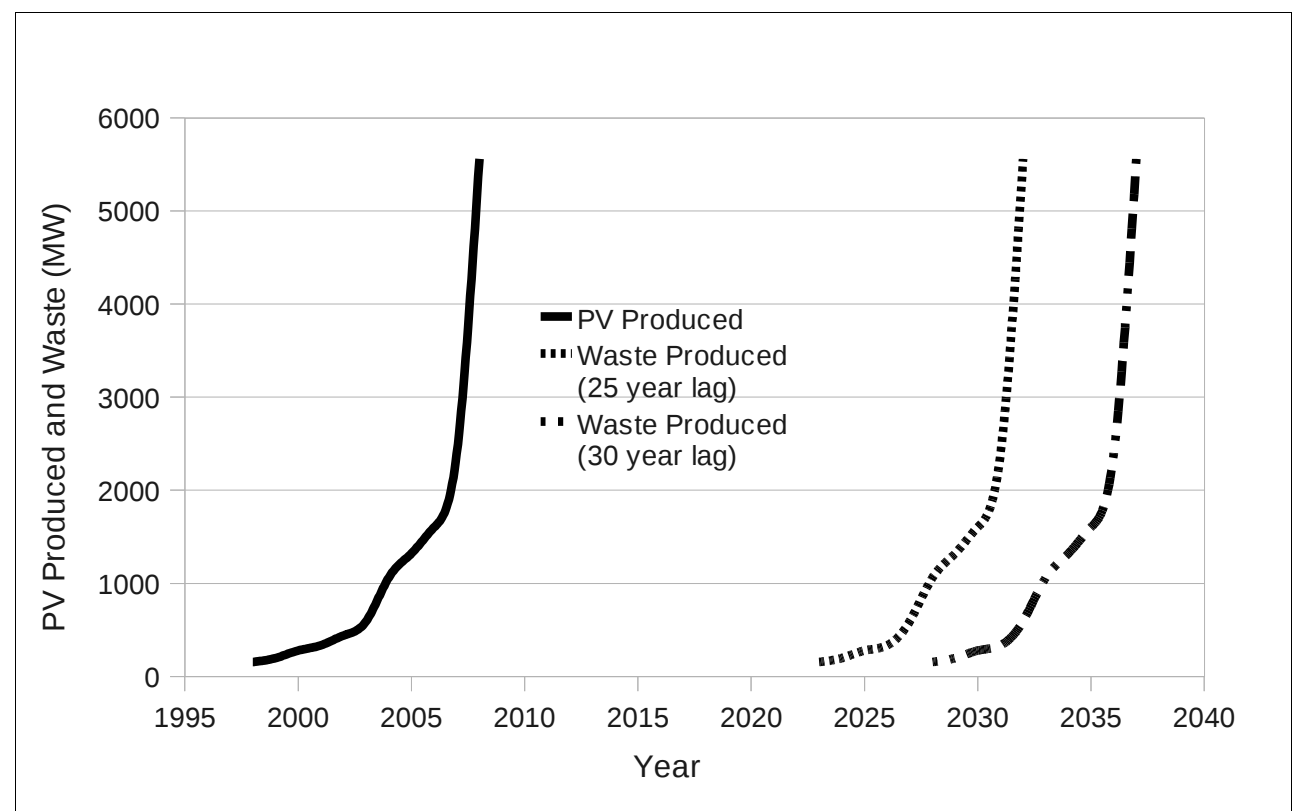

Figure 1: Global PV production and projected waste from 1998 to 2038

Additionally, some solar modules contain hazardous materials such as cadmium, tellurium, lead and selenium. Cadmium compounds are, for example, currently regulated in many countries because of their toxicity to fish and wildlife and because they can pass to humans through the food chain. In China the sale of some solar modules is prohibited because of the policies regulating cadmium in photoelectric semiconductor devices (Kaczmar et al, 2008). Cadmium has also been associated with numerous human illnesses particularly lung, kidney and bone damage and once absorbed in the body, cadmium can remain for decades (Bernard, 2008). It accumulates in the natural environment by leaching into ground water and surface water from landfills, and it can enter the atmosphere through incinerator smokestack emissions (Fthenakis, 2000; Fthenakis and Zweibel, 2003). Effective air pollution control equipment at incinerators traps Cd, which

ends up in the ash and thus causes problems of cadmium in ashfill leachate. Accordingly, it is important to realize that as solar waste is created over the next decades, some of this waste will contain hazardous material, and it will be the responsibility of governments to regulate the safe disposal of these materials. Consequently, this paper examines the potential need for PV recycling incentives and regulation through a review of the recycling protocols for modules using the five major commercialized photovoltaic materials. The results of this review provide the foundation for an analysis that will determine whether there is an economic motivation for manufacturers to voluntarily take responsibility for recycling solar modules, and if not, given the hazardous nature of some of the materials, should policy tools be used to ensure solar module recycling. 
Published as: N.C. McDonald and J. M. Pearce, "Producer responsibility and recycling solar photovoltaic modules”, Energy Policy 38, pp. 7041-7047 (2010). http://dx.doi.org/10.1016/j.enpol.2010.07.023

\section{Solar Photovoltaic Recycling Processes}

In order to determine the economic viability of recycling solar modules, an analysis of the recycling process will be done for five of the largest volume commercialized types of solar cells including: copper indium gallium diselenide (CIGS), cadmium telluride (CdTe), amorphous silicon (a-Si), poly-crystalline silicon (p-Si) and mono-crystalline silicon (c-Si). These five cells can be broken up into two additional categories, conventional " $1^{\text {st }}$ generation" (c-Si and p-Si, which can be referred to as $\mathrm{x}-\mathrm{Si}$ ) and " 2 nd generation" thin-film solar cells (a-Si, CIGS, and CdTe) (Green, 2001).

$\mathrm{x}$-Si based PV are the most common type of solar cell manufactured in the world. In 2008, 86-88\% of solar cell production was that of mono and multi-crystalline silicon

composition (European Commission, 2009). The recycling process for both types of x-Si solar cells is identical and involves pyrolysis, which recovers crystalline silicon wafers from the modules. In this process the ethylene vinyl acetate (EVA) lamination layer is vaporized by the inert atmosphere pyrolysis at about $500^{\circ} \mathrm{C}$ (Fthenakis, 2000).

Thin-film solar cells (CIGS, CdTe, and a-Si) have grown increasingly popular in recent years largely due to their decreased manufacturing costs. However, thin film PV only made up $12-14 \%$ of the total solar cells produced in 2008, but are expected to have a market share of about 25\% by the end of 2010 (Brandsen et al., 2007; European Commission, 2009). The production capacity for thin-film cells almost tripled from 2006 to 2008, growing from 282.4 to $890 \mathrm{MW}_{\text {p }}$ (Brandsen et al., 2007; Solar Buzz, 2009).

The recycling process of CIGS solar cells involves putting the materials through a smeltering process or acid baths to recover the metals, including selenium (Se), indium (In) and gallium (Ga). The glass is processed through thermal decomposition, solvent or acid dissolution to remove any remaining PV layers and is recovered (Eberspacher et al., 1998).

The CdTe PV recycling process involves chemical stripping of the metals and EVA and successive steps of electrodeposition, precipitation and evaporation to separate and recover the metals cadmium and tellurium. In addition, the EVA is skimmed from the chemical solution for potential re-use and the glass and frame are recovered (Fthenakis, 2000).

The semiconductor material in an a-Si solar cell is composed of silicon atoms whose microstructure exhibit no long-range order. Recent advances in controlling light induced degradation with the microstructural properties of the material have assisted in improving the stabilized efficiencies (Wronski et al., 2002b; Pearce et al., 2003; Ferlauto et al., 2004; Konagai et al., 2006). Thus, a-Si cells can now be manufactured with a 10\% stabilized efficiency (Oerlikon, 2009; Osborne, 2010). Due to the high absorption coefficient of a-Si only a very thin layer is needed, which makes it viable for commercial use. As the amount of a-Si material is minute in a given module and of low value as a scavenged material, there is currently no literature explaining the recycling process of amorphous silicon solar cells. It is presumed a-Si based solar cell recycling would be primarily driven to reclaim the substrates using any of the techniques described above. 
Published as: N.C. McDonald and J. M. Pearce, "Producer responsibility and recycling solar photovoltaic modules”, Energy Policy 38, pp. $7041-7047$ (2010). http://dx.doi.org/10.1016/j.enpol.2010.07.023

\section{Methodology}

The comparative analysis performed for the recycling process of the five types of PV material-based solar cells first determines the amount of semiconductor material in a $1 \mathrm{~m}^{2}$ area solar module and finds the amount of recoverable semiconductor material by recycling from the module. The semiconductor materials considered are: indium (In), gallium (Ga), silicon (Si), cadmium sulfide (CdS), cadmium (Cd) and tellurium (Te). Because the recycling process of p-Si and c-Si PV modules is identical, the two types of modules have been grouped together for the analysis. It has also been assumed that all modules use a standard glass substrate/cover, which can be recycled, and are frameless. It should be noted that in the event that a module has a frame (e.g. aluminum) it can be mechanically separated from the module and recycled using well established techniques.

By determining the thickness and density of the semiconductor in each module from literature, the mass of recovered semiconductor in each module after the recycling process can be found using:

$$
m_{r s}=A \times t_{s} \times \rho_{s} \times z_{s} \quad \text { [grams/module] }
$$

where $\mathrm{A}$ in $\mathrm{cm}^{2}$ is the area of the solar module, $\mathrm{t}_{\mathrm{s}}$ is the thickness in $\mathrm{cm}$ of the semiconductor in the solar module, $\rho_{s}$ is the density of the semiconductor material in $\mathrm{g} / \mathrm{cm}^{3}$ and $\mathrm{z}_{\mathrm{s}}$ is the percent of semiconductor material that can be recovered from a solar module, determined from literature.

Given the amount of recovered semiconductor material in each module, and data from the literature for the cost of recycling the solar modules, the profit $\mathrm{P}_{\mathrm{s}}$, made from reselling the semiconductor is given by:

$$
P_{s}=m_{r s} \times V_{s} \quad \text { [\$/module] }
$$

where $\mathrm{V}_{\mathrm{s}}$ is the resale value in dollars/gram of the semiconductor material, $\mathrm{m}_{\mathrm{rs}}$ is determined from equation 1 . All economic values are given in U.S. dollars. Additionally, the mass of recovered glass is given by:

$\mathrm{m}_{\mathrm{rg}}=\mathrm{A} \times \mathrm{t}_{\mathrm{g}} \times \rho_{\mathrm{g}} \times \mathrm{z}_{\mathrm{g}} \quad$ [grams/module]

where $t_{\mathrm{g}}$ is the thickness in $\mathrm{cm}$ of all the glass in the solar module, the percent recovery, $\mathrm{Z}_{\mathrm{g}}$, is assumed here to be $100 \%$ for the glass cullet, and $\rho_{\mathrm{g}}$ is the density of the glass in $\mathrm{g} / \mathrm{cm}^{3}$. Similarly using the results from equation 3 , the profit, $P_{\mathrm{g}}$, of recycling the glass

can be found as:

$$
P_{g}=V_{g} \times m_{g} \quad \text { [\$/module] }
$$

where $\mathrm{V}_{\mathrm{g}}$ is the resale value in dollars of the glass, $\mathrm{m}_{\mathrm{rg}}$ is given by equation 3 .

Finally, the cost of landfill disposal was found for each type of solar module. These results take into account the cost of disposing the whole solar module, including the glass and semiconductor. The total mass of waste per module was calculated using:

$$
W=\frac{A \times E \times W}{N_{p}} \quad \text { [kg/module] }
$$

Where $\mathrm{E}$ is the power per unit area of each module in $\mathrm{W} / \mathrm{m}^{2}$, $\mathrm{w}$ is the weight of the solar module in $\mathrm{kg}$ and $\mathrm{N}_{\mathrm{p}}$ is the nominal power in $\mathrm{W}$ of the solar module.

The final disposal cost was found using: 
Published as: N.C. McDonald and J. M. Pearce, "Producer responsibility and recycling solar photovoltaic modules”, Energy Policy 38, pp. $7041-7047$ (2010). http://dx.doi.org/10.1016/j.enpol.2010.07.023

$D=W \times T$

[\$/module]

where $\mathrm{W}$ is the waste mass per module calculated in equation 5 , and $\mathrm{T}$ is the tipping cost in $\$ / \mathrm{kg}$ determined from the literature. Finally the total profit found from recycling is given by:

$\mathrm{P}_{\mathrm{T}}=\left(\mathrm{P}_{\mathrm{s}}+\mathrm{P}_{\mathrm{g}}\right)+\mathrm{D}-\mathrm{C}=\mathrm{P}_{\mathrm{t}}+\mathrm{D}-\mathrm{C}$

[\$/module]

where $\mathrm{C}$ is the cost of recycling $\$$ /module and $\mathrm{P}_{\mathrm{t}}$ is the sum of $\mathrm{P}_{\mathrm{s}}$ and $\mathrm{P}_{\mathrm{g}}$.

\section{Results: PV Recycling Costs and Profits}

A comparative analysis was done to determine the potential profit of recycling five types of solar modules. In the first step of this analysis, the mass of semiconductor

material in a solar module was determined and compared to the amount which can be recovered from recycling. The input parameters and the mass of the recovered semiconductor material after the recycling process for a $1 \mathrm{~m}^{2}$ panel from equation 1 are outlined in Table 1 for the four types of solar modules: CIGS, CdTe, a-Si and x-Si.

Table 1: Amount of recovered semiconductor material for four solar modules

\begin{tabular}{|c|c|c|c|c|c|c|}
\hline & \multicolumn{2}{|c|}{ CIGS } & \multicolumn{2}{|c|}{ CdTe } & \multirow[t]{2}{*}{ a-Si } & \multirow[t]{2}{*}{$x-S i$} \\
\hline & Ga & In & Cd & $\mathrm{Te}$ & & \\
\hline A $\quad\left(\mathrm{cm}^{2}\right)$ & \multicolumn{2}{|c|}{$10,000^{\mathrm{a}}$} & \multicolumn{2}{|c|}{$10,000^{\mathrm{a}}$} & $10,000^{\mathrm{a}}$ & $10,000^{\mathrm{a}}$ \\
\hline $\mathrm{t}_{\mathrm{s}}(\mathrm{cm})$ & \multicolumn{2}{|c|}{$0.0004^{\mathrm{b}}$} & \multirow{2}{*}{\multicolumn{2}{|c|}{$\frac{0.0003^{\mathrm{c}}}{6.2^{\mathrm{f}}}$}} & $0.00005^{\mathrm{d}}$ & $0.02^{\mathrm{e}}$ \\
\hline$\rho_{s}\left(g / \mathrm{cm}^{3}\right)$ & N/A & N/A & & & $2.33^{\mathrm{f}}$ & $2.33^{\mathrm{f}}$ \\
\hline$m_{s}(g)$ & 6.54 & 10.77 & $9.07^{\mathrm{g}}$ & $9.53^{8}$ & 1.165 & 466 \\
\hline $\mathrm{z}_{\mathrm{s}}(\%)$ & \multicolumn{2}{|c|}{80} & $99^{\mathrm{h}}$ & $96^{\mathrm{h}}$ & N/A & $60^{\mathrm{h}}$ \\
\hline$m_{\mathrm{rs}}(\mathrm{g})$ & 5.23 & 8.62 & 8.98 & 9.15 & $<1.17$ & 279.6 \\
\hline
\end{tabular}

There is currently no information in PV recycling literature to suggest that recycling a-Si solar modules is performed. This is likely because the mass of semiconductor material in an a-Si module is so minute and the value of a-Si is so small that the value is negligible. This conclusion is supported by the results in Table 1, which shows that the mass of semiconductor material in a $1 \mathrm{~m}^{2} \mathrm{a}-\mathrm{Si}$ solar module is about $1 \mathrm{~g}$. As a result, the value of the a-Si will not be used for further cost analyses here as the relative value will become clear when the value of the glass and avoided waste tipping fee are quantified below.

Next the amount of recovered glass after recycling is determined and the results are found in Table 2. As can be seen in Table 2 for all the types of modules the mass is

between 16 and $17 \mathrm{~kg}$ per square meter.

Table 2: Determining mass of recovered glass for CIGS, CdTe, and c-Si PV modules

\begin{tabular}{|c|c|c|c|}
\hline & CIGS & CdTe & c-Si \\
\hline $\begin{array}{ll}A & \left(\mathrm{~cm}^{2}\right)\end{array}$ & $10,000^{\mathrm{a}}$ & $10,000^{\mathrm{a}}$ & $10,000^{2}$ \\
\hline$t_{g}(\mathbf{c m})$ & $0.68^{\mathrm{b}}$ & $0.64^{\mathrm{C}}$ & $0.64^{\mathrm{d}}$ \\
\hline
\end{tabular}


Published as: N.C. McDonald and J. M. Pearce, "Producer responsibility and recycling solar photovoltaic modules”, Energy Policy 38, pp. $7041-7047$ (2010). http://dx.doi.org/10.1016/j.enpol.2010.07.023

\begin{tabular}{|l|c|c|c|}
\hline $\mathbf{\rho}_{\mathbf{g}}\left(\mathbf{g} / \mathbf{c m}^{3}\right)$ & $2.6^{\mathrm{e}}$ & $2.6^{\mathrm{e}}$ & $2.6^{\mathrm{e}}$ \\
\hline $\mathbf{m}_{\mathbf{r g}}(\mathbf{g})$ & 17,680 & 16,640 & 16,640 \\
\hline Sources: (a) Assumed area of $1 \mathrm{~m}^{2}$ (b) Xsunx (2009) (c) First Solar (2009b) (d) BP \\
Solar (2009a) (e) Giancoli (1998) \\
\hline
\end{tabular}

The third step in the comparative analysis was to use equations 2 and 4 to determine and compare the cost of recycling each of the three remaining solar modules and the financial return from re-selling the recovered semiconductor material and the glass in each. The results of this analysis are found in Table 3.

Table 3: Recycling cost and recycling profit for three solar modules

\begin{tabular}{|c|c|c|c|c|c|}
\hline & \multicolumn{2}{|c|}{ CIGS } & \multicolumn{2}{|c|}{ CdTe } & $\mathrm{x}-\mathrm{Si}$ \\
\hline & In & Ga & Cd & Te & $\mathrm{Si}$ \\
\hline $\begin{array}{ll}V_{s} & (\$ / g)\end{array}$ & $3.00^{\mathrm{a}}$ & $3.00^{\mathrm{a}}$ & $0.026^{\mathrm{a}}$ & $0.220^{\mathrm{a}}$ & $0.027^{\mathrm{b}}$ \\
\hline $\mathrm{m}_{\mathrm{rs}} \quad$ (g) & 5.23 & 8.62 & $8.98^{\mathrm{c}}$ & $9.15^{\mathrm{c}}$ & $279.60^{\mathrm{c}}$ \\
\hline$P_{\mathrm{s}}$ (\$/module) & 15.70 & 25.85 & 0.23 & 2.02 & 7.54 \\
\hline$V_{g} \quad(\$ / g)$ & $3.72 \mathrm{E}-06^{\mathrm{d}}$ & $3.72 \mathrm{E}-06^{\mathrm{d}}$ & $3.72 \mathrm{E}-06^{\mathrm{d}}$ & $3.72 E-06^{d}$ & $3.72 \mathrm{E}-06^{\mathrm{d}}$ \\
\hline $\mathbf{m}_{\mathrm{rg}}$ (g) & \multicolumn{2}{|c|}{$17,680^{\mathrm{e}}$} & \multicolumn{2}{|c|}{$16,640^{\mathrm{e}}$} & $16,640^{\mathrm{e}}$ \\
\hline $\mathbf{P}_{\mathrm{g}}(\$ /$ module $)$ & \multicolumn{2}{|c|}{0.07} & \multicolumn{2}{|c|}{0.06} & 0.06 \\
\hline$P_{t}$ (\$/module) & \multicolumn{2}{|c|}{$41.62^{f}$} & \multicolumn{2}{|c|}{$2.31^{f}$} & $7.54^{f}$ \\
\hline $\begin{array}{ll}\mathrm{C} & \text { (\$/module) } \\
\end{array}$ & \multicolumn{2}{|c|}{$20.24^{\mathrm{g}}$} & \multicolumn{2}{|c|}{$9.00^{\mathrm{g}}$} & $32.11^{\mathrm{h}}$ \\
\hline
\end{tabular}

Sources: (a) Radiochemistry Society (2003) (b) Fero et al. (2010) (c) results from Table 1 (d) Three D and UWC (2008) (e) results from Table 2 (f) sum of $P_{s}$ and $P_{g}(g)$ Eberspacher (1998) (h) Fthenakis (2000)

It is clear from Table 3 that the profit made by re-selling the recovered semiconductor material and glass, $\mathrm{P}_{\mathrm{t}}$, from CIGS solar modules greatly exceeds the cost of recycling these modules. However, in the case of CdTe and x-Si solar modules, the cost of recycling the module is more than the money made from re-selling the recovered materials. However, there is also an economic benefit from diverting panels from landfills. This economic benefit is only experienced by the manufacturers if there is an existing manufacturing responsibility legislation in place.

To calculate this benefit the cost of landfill disposal for each type of solar module from equation 6 is used and the results of this analysis are found in Table 4. 
Published as: N.C. McDonald and J. M. Pearce, "Producer responsibility and recycling solar photovoltaic modules”, Energy Policy 38, pp. $7041-7047$ (2010). http://dx.doi.org/10.1016/j.enpol.2010.07.023

Table 4: Landfill disposal cost of PV modules and total profitability of recycling

\begin{tabular}{|c|c|c|c|c|c|}
\hline & CIGS & CdTe & c-Si & p-Si & a-Si \\
\hline E (W/m $\mathbf{2})$ & $100^{\mathrm{a}}$ & $108^{\mathrm{a}}$ & $144^{\mathrm{a}}$ & $138^{\mathrm{a}}$ & $90^{\mathrm{a}}$ \\
\hline Weight (kg) & $28^{\mathrm{b}}$ & $12^{\mathrm{c}}$ & $15.4^{\mathrm{d}}$ & $19.4^{\mathrm{e}}$ & $19.1^{\mathrm{f}}$ \\
\hline Nominal Power (W) & $160^{\mathrm{b}}$ & $77.5^{\mathrm{c}}$ & $180^{\mathrm{d}}$ & $230^{\mathrm{e}}$ & $128^{\mathrm{f}}$ \\
\hline $\mathbf{W ~ ( k g / m o d u l e ) ~}$ & $17.5^{\mathrm{b}}$ & $16.72^{\mathrm{c}}$ & $12.32^{\mathrm{d}}$ & $11.64^{\mathrm{e}}$ & $13.43^{\mathrm{f}}$ \\
\hline $\mathbf{T ~ ( \$ / k g )}$ & $0.05^{\mathrm{g}}$ & $0.39^{\mathrm{g}}$ & $0.05^{\mathrm{g}}$ & $0.05^{\mathrm{g}}$ & $0.05^{\mathrm{g}}$ \\
\hline $\mathbf{D} \mathbf{( \$ )}$ & 0.87 & 6.45 & 0.61 & 0.58 & 0.67 \\
\hline $\mathbf{P}_{\mathbf{T}}=\mathbf{P}_{\mathbf{t}}+\mathbf{D}-\mathbf{C} \mathbf{( \$ )}$ & 22.25 & -0.24 & -23.96 & -23.99 & $0.73-\mathrm{C}$ \\
\hline
\end{tabular}

Sources: (a) Von Roedern (2009) (b) Xsunx (2009) (c) First Solar (2009b) (d) BP Solar (2009a) (e) BP Solar (2009b) (f) Sharp (2009) (g) Lee (1995)

It is evident from Table 4 that the cost of landfilling the CdTe modules is considerably higher than the other types of modules because this module contains a substantial amount of cadmium, which is toxic heavy metal and considered a hazardous

material. This is economically beneficial for the recycling mandate, but unfortunately the magnitude is not great enough to keep the total profitability of recycling CdTe modules from being negative. Thus the CdTe modules are not profitable to recycle, but the relatively small cost of recycling is likely worth the goodwill generated by being environmentally responsible.

In addition all the silicon-based modules are not profitable to recycle. The case of a-Si is not quantified but it is clear from the costs to recycle the other types of modules that $\mathrm{P}_{\mathrm{T}}$ would be largely negative. Although it should be noted it may be possible to recycle the top glass as pre-deposited solar substrates with the transparent conducing oxide intact. Further work is required to determine the viability of this scheme, which would improve the economics considerably for all of the thin film modules.

Overall Table 4 indicates that there is no economic motivation for recycling, therefore because some materials are hazardous and recycling is critical, there is a need to provide policies to ensure recycling as the economic case for recycling using the current economic system, which ignores most environmental and social externalities. It should be pointed out that in the economically viable case of CIGS, because most CIGS modules contain a buffer layer of $\mathrm{CdS}$, the recycling and landfilling may also be costly (Alsema et al., 2005). Thus, the value in Table 4 must be considered a lower estimate and the economic incentive to recycle CIGS would be even greater than indicated. It can be drawn from comparing Table 3 and Table 4, that the cost of landfill disposal for each of the solar modules is extremely low when compared to the cost of recycling, which

indicates that there may be a need for some non-market based approach to ensuring environmental sustainability - whether it be through corporate social responsibility or governmental regulations against disposal for industry to make an investment in 
Published as: N.C. McDonald and J. M. Pearce, "Producer responsibility and recycling solar photovoltaic modules”, Energy Policy 38, pp. 7041-7047 (2010). http://dx.doi.org/10.1016/j.enpol.2010.07.023

recapturing the materials from PV modules, even if it is profitable as seen in Table 4.

\section{Discussion}

\subsection{Existing Photovoltaic Recycling Initiatives}

It can be assumed that based on the analysis above CIGS modules will be recycled due to the value of the materials they contain, but for the other modules some additional incentive is necessary. Therefore, it is essential that producer responsibility is developed among manufacturers to ensure the proper disposal methods are undertaken for solar PV modules. There are three main recycling initiatives that have already been voluntarily developed by PV manufacturers that may be generalized to be used as models: First Solar, SolarWorld Global, and PV Cycle.

First Solar is an American company that was formed in 1999, and launched production of CdTe-based PV commercial products in 2002. They have shown some commitment to the environment by ensuring that all stages of the PV manufacturing process, including end-of-life, create low carbon emissions. Consequently they claim that their carbon footprint is the lowest among available PV technologies, and compares well with wind technologies (Lincot, 2009). Additionally, in anticipation of potential negative backlash for using a toxic heavy metal in a 'green' product, more recently the company has undertaken a collection and recycling program (First Solar, 2009a; 2010). With the sale of each module, First Solar sets aside sufficient funds required for the estimated future cost of collection and recycling in custodial accounts in the name of a Trustee and the program, including the financing structure, is audited annually by an independent third party (First Solar, 2010). This collection and recycling program involves three steps: registering each module that the company sells, collecting these modules once they are decommissioned and recycling the modules to recover materials (First Solar, 2009a). The company also pays all packaging and transportation costs associated with the collection of the decommissioned modules. This program is a useful model as it covers the most environmentally dangerous photovoltaic-related solid waste and provides an example for other CdTe manufacturers. However, this program is only designed to recycle solar cells that First Solar has manufactured, so policy would need to ensure that each company also instituted such a program.

The second example program was developed by SolarWorld AG and their subdivision SolarMaterial, which focuses on many aspects of the PV module life cycle, including the recycling phase. Their program is designed to recycle modules of all designs and sizes that have undergone any type of damage (e.g. glass breakage, defective laminate, or electrical faults) (SolarMaterial, 2009). As a result of this project, and SolarWorld's overall environmental leadership, the company was ranked first overall among crystalline PV manufacturers in a report by the Silicon Valley Toxic Coalition because of their performance on environmental and social responsibilities (Santarris, 2010). Based on this award, clearly one of the benefits for SolarWorld is goodwill. However, because this program includes all types of solar modules, the economic analysis above indicates it may not be in the benefit of the company to maintain the program in the future. 
Published as: N.C. McDonald and J. M. Pearce, "Producer responsibility and recycling solar photovoltaic modules”, Energy Policy 38, pp. 7041-7047 (2010). http://dx.doi.org/10.1016/j.enpol.2010.07.023

Unlike the two previous examples of company specific programs, PV Cycle is a program that was created by the European PV manufacturing industry. The program was founded in 2007 to implement the PV industry's commitment to set up a voluntary take back and recycling program (PV Cycle, 2009). The manufacturers, which make up PV Cycle embrace the concept of producer responsibility and aim to offer a completely sustainable solar energy solution. However, this type of initiative only works if the industry is inclined to voluntarily participate in environmentally responsible manufacturing, which is not yet applicable globally. Without this type of initiative being regulated, manufacturing companies are free to withdraw from the program.

\subsection{Producer Responsibility in PV Manufacturing}

The initial cost of landfill disposal for all five solar modules is lower than the cost of recycling the modules, which will still make landfill more favorable than recycling for companies with short-term thinking even if the recycling is profitable overall. From the results above it is clear that: 1) CIGS PV will likely be recycled for profit, 2) CdTe manufacturing is dominated by First Solar, which has set a good example of a relatively low-cost recycling program for this technology, 3) some companies like SolarWorld may offer recycling programs for goodwill, but are unlikely to continue to provide economic loss leaders as the volume of waste PV increases, and 4) producer responsibility is needed to recycle Si-based PV as demonstrated by PV Cycle in Europe and to ensure that modules containing hazardous materials are disposed of appropriately. This final methodology of manufacturing responsibility, is the most generalizable as the first three are constrained by specific situations.

Although there are other policy techniques such as mandated consumer recycling to ensure products containing hazardous materials are disposed of appropriately, in the PV case there is clear advantage of using manufacturing responsibility because of the way government is supporting the industry to break into the energy market. For example, Abound Solar Manufacturing was recently offered a US $\$ 400$ million loan guarantee to build two plants to manufacture CdTe-based solar panels during Obama's $4^{\text {th }}$ of July announcement (Goossens, 2010). This will be the first time this technology for manufacturing solar panels is deployed commercially anywhere in the world, yet Abound will reach full manufacturing capacity in 2013, when they expect to produce more than 0.84 GW of PV modules annually (Goossens, 2010). To put that manufacturing capacity in perspective, consider that this relatively unproven company will be producing more PV panels than the aggregate of the entire global PV industry in 2003 only because of government assistance. Clearly, the government is in a position to demand extended manufacturing responsibility for such companies producing products containing hazardous materials. Utilizing manufacturing responsibility as a means to ensure proper disposal of PV-related hazardous waste will ensure that the burden is not foisted on consumers.

The concept of extended manufacturing responsibility states that the life cycle impacts of a product are viewed as the responsibility of the manufacturers and producers that create them (Larsen, 2009). In the manufacturing sector this concept is relatively 
Published as: N.C. McDonald and J. M. Pearce, "Producer responsibility and recycling solar photovoltaic modules”, Energy Policy 38, pp. 7041-7047 (2010). http://dx.doi.org/10.1016/j.enpol.2010.07.023

well developed as compared to the energy sector. Larsen explains that this idea of extended manufacturing responsibility should involve testing new materials and processes, expanding recycling technologies, and designing products to be more easily recycled (Larsen, 2009). In the PV industry, a benefit of an environmentally responsible market is the possibility that materials from the decommissioned PV cells can be recovered and re-used, which may become important, as there has recently been discussion in the PV industry of declining amounts of cadmium, indium and tellurium (Larsen, 2009). This material shortage could lead to increased material prices and production costs of PV solar cells (Feltrin and Freundlich, 2006); and may make recycling solar modules more favorable because many of the semiconductor materials, can be recovered and re-used by recycling decommissioned solar cells. In a given region, if the PV manufacturing industry does not voluntarily adopt manufacturing responsibility as was done with PV Cycle, the government must assume its environmental responsibility and regulate the PV manufacturing industry to ensure recycling and avoid hazardous materials from entering local landfills. This will create a competitive advantage for companies that either work hard to avoid toxic materials (which entail a larger cost for recycling), or have already instituted recycling programs. Thus the environmentally most responsible companies are rewarded for their investments.

\subsection{Producer Responsibility for Similar Hazardous Products}

Regulation has been used in technology sectors across the world as a driver for recycling of hazardous products. Nickel-cadmium (NiCd) batteries and cathode ray tube (CRT) televisions and monitors contain materials similar to those found in some PV modules, and both saw increased recycling and take-back programs following government regulation. The PV industry can gain from observing past efforts to manage the recycling of similar hazardous products.

The amount of Cd contained in a $1 \mathrm{~m}^{2} \mathrm{CdTe}$ solar module is very similar to that in a size AA or size C NiCd battery (about 3-10g) (Fthenakis, 2003). The Mercurycontaining and Rechargeable Battery Management Act was established in 1996 (EPA, 1996) to accomplish two goals: to phase out batteries that use mercury and to develop collection, transportation and most importantly recycling and proper disposal for NiCd batteries (Palchy, 2003). Additionally, in the U.S., eight states created legislation that mandated producer responsibility among NiCd battery manufacturers. Through this legislation, the NiCd industry instituted a national take-back program (Fishbein, 1996). Moreover, there have been independent NiCd recycling facilities and take-back programs that have been established to manage the hazardous cadmium waste in NiCd batteries (Palcy, 2003). For example Kodak developed a take-back and recycling program for their used cameras, which is currently recycling upwards of 1 billion cameras, and ensures that 90\% of new cameras developed come from recycled cameras (Fishbein, 1996).

During the $1^{\text {st }}$ International Conference on PV Module Recycling in Berlin, Germany, Döring argues that one can look at Germany's experience in recycling cathode ray tube (CRT) TV monitors, because the material composition is similar to PV modules (2010). One of the major drivers that led to CRT recycling in Germany was the regulation 
Published as: N.C. McDonald and J. M. Pearce, "Producer responsibility and recycling solar photovoltaic modules”, Energy Policy 38, pp. 7041-7047 (2010). http://dx.doi.org/10.1016/j.enpol.2010.07.023

for electronic waste (Döring, 2010). This regulation stemmed from the Waste Electrical and Electronic Equipment (WEEE) Directive set forth by the European Commission in 2003, which utilizes the Polluter Pays Principle (Kibert, 2004). The Directive essentially mandates producers to be responsible for taking back and recycling products they manufacture at no cost to the consumer (Kibert, 2004), thereby creating extended producer responsibility within the electrical and electronic equipment industry.

\subsection{Producer Responsibility in the Energy Industry}

There is obviously a concern that regulating PV manufacturers to ensure they make the investment to recycle their products will have an un-intended consequence of providing a competitive advantage to other forms of electricity production. As most electricity is created from the combustion of fossil fuels or the fission of uranium it is clear that any disadvantage to the PV manufacturing industry caused by mandated recycling could actually increase environmental damage unless other members of the energy industry were similarly mandated. The concept of applying producer responsibility to the traditional energy industry is relatively unexplored and provides a rich area for future inquiry. Researchers have just begun to look at externalities in the nuclear industry such as the indirect subsidies inherent in nuclear energy insurance caps (Dubin and Rothwell, 1990; Heyes, 2003; Pearce, 2009) and work focused on quantifying the costs of externalities of fossil fuel use has started (Ambs and Roth, 2004; Eyre, 1997; Klaassen and Riahi, 2007; Owen, 2006), but rarely applied through mechanisms like carbon pricing and taxing (Flavin and Lenssen, 1992; Mathews, 2007; Sterner, 2007). It is clear that such work is imperative to correct for the current market failures that provide advantages to environmentally and socially irresponsible 'manufacturers' of energy.

\section{Conclusions}

This paper examined the potential need for solar PV recycling policies by analyzing existing recycling protocols for the five major types of commercialized PV materials. It was found that the economic motivation to recycle most types of PV devices does not outweigh the difference between recycling and landfill costs, thereby making recycling an unfavorable economic option without appropriate incentives. Nonetheless, some solar manufacturing companies have begun to voluntarily recycle solar modules, but such initiatives are driven by environmental responsibility rather than economic benefit. Therefore, as PV waste appears 25-30 years after the module is created and the PV industry is experiencing explosive growth, there will be increased need to recycle the large amount of decommissioned solar modules. Because recycling is economically unfavorable, this will ultimately lead to economic stress on voluntary initiatives. Consequently, unless recycling of solar modules is regulated in the future, it is likely that these types of voluntary initiatives will not be maintained and hazardous materials will begin to enter local waste streams However, it is critical that regulation of recycling in PV manufacturing does not provide a competitive advantage to the more environmentally destructive forms of electricity production. Therefore, it is imperative that appropriate policies are instituted taking the future into account and minimizing environmental 
Published as: N.C. McDonald and J. M. Pearce, "Producer responsibility and recycling solar photovoltaic modules”, Energy Policy 38, pp. 7041-7047 (2010). http://dx.doi.org/10.1016/j.enpol.2010.07.023

pollution and solid waste from electricity production.

\section{Acknowledgments}

The authors would like to acknowledge support from Natural Sciences and Engineering Research Council of Canada and helpful discussions with H. Nguyen and I. ZelenikaZovko.

\section{References}

Ahn, B.T., Chung, G.Y., Han, B.W., 1998. Photovoltaic properties of CdTe solar cells fabricated by close spaced sublimation with screen printed CdTe sources. Solar Energy Materials and Solar Cells 50, 155-161.

Alsema, E.A., de Wild-Scholten, M.J., Jager-Waldau, A., Wamback, K., 2005. Implications of European Environmental Legislation for Photovoltaic Systems. $20^{\text {th }}$ European Photovoltaic Solar Energy Conference. Barcelona, Spain.

Ambs, L., Roth, I., 2004. Incorporating externalities into a full cost approach to electric power generation life-cycle costing. Energy, 29(12-15), 2125-2144.

Angrist, S., 1982. Direct energy conversion, Allyn and Bacon, Boston.

Applied Materials, 2009. Energy and Environment Technical Glossary, Accessed 16 November, 2009. Available at http://www.appliedmaterials.com/products/glossary_ee.html

Bernard, A. 2008. Cadmium \& its adverse effects on human health. Indian Journal of Medical Research. 128(4), 557-64.

Boyeaux, J.P., Fave, A., Kaminski, A., Laugie, A., 2001. Local characterization of large area multicrystalline solar cells by non-destructive mapping. Materials Science in Semiconductor Processing 4, 261-263.

BP Solar, 2009a. 180 Watt Photovoltaic Module: BP 4180T, Accessed 9 December,

2009. Available at http://files.buildsite.com/dbderivedf/bpsolar/derived_files/derived380424.pdf

BP Solar, 2009b. 210, 220 and 230W Photovoltaic Modules of Poly 3 Series: BP 3210N, BP 3220N, BP 3230N, Accessed 1 December, 2009. Available at http://www.gemeinhardt.ag/uploads/media/Prospekt_BP_Endura_3220N_01.pdf Brandsen, G.W., Fleuster, M., Hekkert., M.P., van Sark, W., 2007. Analysis of the Silicon Market: Will Thin Films Profit? Energy Policy 35, 3121-3125.

Branker, K., Pearce, J.M., 2010. Financial Return for Government Support of LargeScale Thin-Film Solar Photovoltaic Manufacturing in Canada. Energy Policy 38, 4291-4303.

Carex, 2010. Cadmium and its compounds. Accessed 6 July 2010. Available at http://www.carexcanada.ca/en/cadmium.pdf

Castanas, E., Kampa, M., 2008. Human health effects of air pollution. Environmental Pollution 151, 362-367.

Cheyney, T., 2009. Poll: Vast majority of Americans believe in development, use of solar 
Published as: N.C. McDonald and J. M. Pearce, "Producer responsibility and recycling solar photovoltaic modules”, Energy Policy 38, pp. $7041-7047$ (2010). http://dx.doi.org/10.1016/j.enpol.2010.07.023

energy. News Release, PV-tech.org, October 8, 2009, Accessed 1 April, 2010. Available at http://www.pvtech.org/news/_a/poll_vast_majority_of_americans _believe_in_development_use_of_solar_energy

Döring, E. 2010. Experiences from TV-Monitor (CRT Glass) Recycling. Presentation $1^{\text {st }}$ International Conference on PV Module Recycling. Berlin, Germany.

Dubin, J. A. and Rothwell, G. S., 1990. Subsidy to Nuclear-Power through PriceAnderson Liability Limit. Contemporary Policy Issues 8, 73-79.

Eberspacher, C., Fthenakis, V.M., Moskowitz, P.D., 1998. Recycling strategies to enhance the commercial viability of CIS photovoltaics. Progress in Photovoltaics: Research and Applications 4, 447-456.

Edoff, M., 2004. Thin Film Solar Cells based on CIS. European Commission RTD Renewable Energies Press Briefing. Uppsala, Sweden.

EPIA. 2009. Global market outlook for photovoltaics until 2013. Commissioned Publication. Brussels, Belgium.

EPA, 1996. PUBLIC LAW 104-142. $104^{\text {th }}$ Congress.

European Commission, 2009. PV Status Report: 2009. Commissioned Publication.

Eyre, N., 1997. External costs: What do they mean for energy policy. Energy Policy, 25(1), 85-95.

Feltrin, A., Freundlich, A., 2006. Material Challenges for Terawatt Level Deployment of Photovoltaics. Photovoltaic Energy Conversion 2, 2469-2472.

Ferlauto, A. S., Ferreira, G. M., Pearce, J. M., Wronski, C. R., Collins, R. W., Deng, X., Ganguly, G., 2004. Analytical Model for the Optical Functions of Amorphous Semiconductors and Its Applications in Thin Film Photovoltaics. Thin Solid

Films 455-456, 388-392.

Fero, C., Hazeltine, B., Qin, W., 2010. Advancements in the commercial production of polysilicon. Photovoltaics World magazine, Accessed 10 June, 2010. Available at http://www.electroiq.com/index/display/photovoltaics-articledisplay/0380184934/ articles/Photovoltaics-World/volume-20100/issue-3/features/advancementsin_the.html

First Solar, 2009a. Company Overview website, Accessed 20 November, 2009. Available at http://www.firstsolar.com/company_overview.php

First Solar, 2009b. First Solar FS Series 2 PV Module, Accessed 20 November, 2009. Available at http://www.firstsolar.com/pdf/PD_5_401_02_NA.pdf

First Solar, 2010. Prefunded Collection and Recycling Program. Accessed 16 June, 2010. Available at: http://www.firstsolar.com/en/recycle_program.php

Fishbein, B., 1996. Extended Producer Responsibility: A New Concept Spreads Around the World. Rutgers University Demanufacturing Partnership Program Newsletter, $1(2)$.

Flavin, C., Lenssen, N., 1992. Policies for a solar economy. Energy Policy, 20(3), 245256.

Fthenakis, V.M., 2000. End-of-life management and recycling of PV modules. Energy Policy 28, 1051-1058.

Fthenakis, V.M., 2003. CdTe PV: Facts and Handy Comparisons. Brookhaven National 
Published as: N.C. McDonald and J. M. Pearce, "Producer responsibility and recycling solar photovoltaic modules”, Energy Policy 38, pp. 7041-7047 (2010). http://dx.doi.org/10.1016/j.enpol.2010.07.023

Laboratory.

Fthenakis, V.M, Zweibel, K., 2003. CdTe PV: Real and Perceived EHS Risks.

Presentation National Center for Photovoltaics and Solar Program Review Meeting. Denver, Colorado.

Frantzeskaki, N., Gekas, V., Tsoutsos, T., 2005. Environmental impacts from the solar energy technologies. Energy Policy 33, 289-296.

Giancoli, D.C., 1998. Physics, Principles with Applications, $5^{\text {th }}$ Edition.New Jersey: Prentice Hall, 276.

Goossens, E. 2010. Abound to Use \$400 Million U.S. Government Loan Guarantee to Build Plants. Bloomberg, Jul 6, 2010.

Government of Ontario, 2010. \$7-Billion Investment Means Green Energy And 16,000

New Jobs For Ontario. Press Release, voiceoftoronto.com, January 26, 2010, Accessed 20 February 2010. Available at

http://voiceoftoronto.com/wp/2010/01/7-billion-investment-means-green-energyand-16000-new-jobs-for-ontario/.

Green, M.A., 2001. Third Generation Photovoltaics. Bridge Printery: Sydney, Australia.

Heyes, A. 2003. Determining the Price of Price-Anderson, Regulation 25(4), 105-110.

Intergovernmental Panel on Climate Change (IPCC), 2008. Climate Change 2007:

Synthesis Report. Intergovernmental Panel on Climate Change. Cambridge

University Press: Cambridge, United Kingdom.

Jager-Waldau, A., 2007. Photovoltaics and renewable energies in Europe. Renewable and Sustainable Energy Reviews 11, 1414-1437.

Kaczmar, S.W., Kriegner, C.J., Traister, M., Schew, W.A., Sinha, P., Wilson, D.J., 2008. Regulatory policy governing cadmium-telluride photovoltaics: A case study contrasting life cycle management with the precautionary principle. Energy Policy, 36: 381-387.

Kazmerski, L.L., 2006. Solar photovoltaics R\&D at the tipping point: A 2005 technology overview. Journal of Electron Spectroscopy and Related Phenomena 150, 105135.

Kenny, R., Law, C. Pearce, J.M., 2010. Towards Real Energy Economics: Energy Policy Driven by Life-Cycle Carbon Emission. Energy Policy 38, 1969-1978.

Kibert, N.C., 2004. Extended Producer Responsibility: A Tool for Achieving Sustainable Development. Journal of Land Use, 19(2): 503-523.

Klaassen, G., Riahi, K., 2007. Internalizing externalities of electricity generation: An analysis with MESSAGE-MACRO. Energy Policy, 35(2), 815-827.

Konagai, M., Kwak, J.H., Kwon, S.W., Lim, K.S., Myong, S. Y., Pearce, J.M., 2006. Good stability of protocrystalline silicon multilayer solar cells against light irradiation originating from vertically regular distribution of isolated nano-sized silicon grains. $4^{\text {th }}$ World Conference on Photovoltaic Energy Conversion Proceedings, 492. 
Published as: N.C. McDonald and J. M. Pearce, "Producer responsibility and recycling solar photovoltaic modules”, Energy Policy 38, pp. $7041-7047$ (2010). http://dx.doi.org/10.1016/j.enpol.2010.07.023

Larsen, K., 2009. End-of-life PV: then what? Renewable Energy Focus 10, 48-53.

Lee, G. F., 1995. Management of Hazardous Wastes: Issues in Mexico. Presentation Greenpeace Mexico Conference. San Luis Potosi, Mexico.

Lincot, D., 2009. Summary Report: Environmental, Health, and Safety (EHS) Aspects of First Solar Cadmium Telluride (CdTe) Photovoltaic (PV) Systems.

Commissioned report by the French Ministry of Ecology, Energy, Sustainable Development, and the Sea.

Mathews, J., 2007. Seven steps to curb global warming. Energy Policy, 35(8), 42474259.

Oerlikon Solar, 2009. Oerlikon Solar Presents Record Cell Efficiency confirmed by

NREL. Press Release, EU PVSEC, Accessed 6 December, 2009. Available at http://www.oerlikon.com/ecomaXL/index.php?site=OERLIKON EN press_releases_detail\&udtx_id=7080

Osborne, M. 2010. Sharp starts production at 1GW capacity thin-film plant. March 29, 2010, Accessed 10 April, 2010. Available at http://www.pvtech.org/news/_a/sharp_starts_production_at_1gw_capacity_thin_film_plant/

Owen, A., 2006. Renewable energy: externality costs as market barriers. Energy Policy, 34(5), 632-642.

Pearce J.M., 2002. Photovoltaics - a path to sustainable futures. Futures 34, 663-674.

Pearce, J.M. 2009. Increasing PV Velocity by Reinvesting the Nuclear Energy Insurance Subsidy into Large Scale Solar Photovoltaic Production. Proceedings of the $34^{\text {th }}$ IEEE Photovoltaic Specialists Conference, 1338-1343.

Plachy, 2003. Cadmium Recycling in the United States in 2000. US Geological Survey. Accessed 6 July, 2010. Available at http://www.p2pays.org/ref/45/44135.pdf

PV Cycle, 2009. Making Photovoltaics “Double Green”, Accessed 6 December, 2009. Available at http://www.pvcycle.org/index.php?id=4

Radiochemistry Society, 2003. Periodic Table of the Elements, Accessed 6 December, 2009. Available at http://www.radiochemistry.org/periodictable/index.shtml

Santarris, B., 2010. SolarWorld earns top score among conventional module makers in tech watchdog group's sustainability 'scorecard'. Press Release, SolarWorld, March 23, 2010, Accessed 6 December, 2009. Available at http://www.solarworld-usa.com/SolarWorld-earns-top-s.4455.0.html.

Sharp, 2009. 128/121/115 Watt: Thin Film Module, Accessed 6 December, 2009. Available at http://www.sharpusa.com/SolarElectricity/SolarProducts/ /media/ Files/Solar/Solar_Products/Solar_Products_Thin_Film/sol_ dow_NA_V121H5.ashx

SolarMaterial, 2009. Module Recycling, Accessed 6 December, 2009. Available at http://www.solarworld.de/solarmaterial/english/company/

SolarWorld, 2009. About Us website, Accessed 6 December, 2009. Available at http://www.solarworld-usa.com/About-us.155.0.html

Solar Buzz, 2009. World PV Industry Report Summary, Accessed 10 June, 2010. Available at http://www.solarbuzz.com/Marketbuzz2009-intro.htm 
Published as: N.C. McDonald and J. M. Pearce, "Producer responsibility and recycling solar photovoltaic modules”, Energy Policy 38, pp. $7041-7047$ (2010). http://dx.doi.org/10.1016/j.enpol.2010.07.023

Solar Buzz, 2010. Solarbuzz Reports World Solar Photovoltaic Market Grew to 7.3 Gigawatt in 2009, Accessed 11 June, 2010. Available at http://www.solarbuzz.com/marketbuzz2010-intro.htm

Sterner, T., 2007. Fuel taxes: An important instrument for climate policy. Energy Policy, 35(6), 3194-3202.

Three D and USW, 2008. Glass Cullet Container and Aggregate Recycling Prices, Accessed 3 March, 2010. Available at http://scrapmetalpricesandauctions.com/ 2008/11/glass-cullet-container-and-aggregate-recycling-prices/

Xsunx, 2009. Preliminary Specification Sheet CIGS Thin Film Solar Modules, Accessed 3 March, 2010. Available at http://www.xsunx.com/pdf/CIGSBrochure-draft.pdf 